\title{
KEGIATAN PENGHIJAUAN DI AREAL HUTAN PENDIDIKAN UNIVERSITAS MUHAMMADIYAH MATARAM
}

\author{
Ibrahim 1), Harry Irawan Johari'1), Mas'ad'1), Nurin Rochayati'1), Khosiah'1), Sukuryadi'1), \\ Agus Herianto'), Arif'), Junaidin"1), Mahsup2)
}

\author{
1)Program Studi Pendidikan Geografi, FKIP, Universitas Muhammadiyah Mataram, Mataram, NTB, Indonesia \\ 2)Program Studi Pendidikan Matematika, FKIP, Universitas Muhammadiyah Mataram, Mataram, NTB, Indonesia \\ Corresponding author : Ibrahim \\ E-mail : ibrahimali.geo@gmail.com
}

Diterima 11 Februari 2021, Direvisi 05 April 2021, Disetujui 05 April 2021

\begin{abstract}
ABSTRAK
Kegiatan penghijauan sebagai bentuk usaha melalui penanaman pohon. Kegiatan ini akan mampu memberi manfaat bagi masyarakat sekitar dalam mendukung social ekonomisecara berkelanjutan. Kegiatan pengabdian ini dengan tujuan : 1) Meningkatkan kesadaran masyarakat dan mahasiswa terhadap pentingnya keutuhan lingkungan sekitar ; 2) Memberikan pengalaman baru pada masyarakat dan mahasiswa mengenai tata cara penanaman pohon dan pemeliharaan secara berkelanjutan; dan 3) Menambah pengetahuan masyarakat dan mahasiswa mengenai pengelolaan pohon pada daerah hutan sebagai sarana pemanfaatan bagi masyarakat sekitarnya. Metode pengabdian yang digunakan dalam kegiatan ini adalah sosialisasi, Pelaksanaan kegiatan padat karya dan evaluasi program. Pengabdian ini dilaksanakan pada tanggal 8 Februari 2021. Kegiatan penghijauan ini dilaksanakan pada Dusun Batu Bolong Desa Batu Layar Barat Kecamatan Batu Layar. Kegiatan penghijauan ini melibatkan mahasiswa dan dosen Pendidikan Geografi FKIP Universitas Muhammadiyah Mataram serta masyarakat dalam menjaga dan melestarikan pohon. Hasil Kegiatan memiliki dampak terhadap penghijau lingkungan sekitar dalam mendukung areal hutan Pendidikan di masa akan dating.
\end{abstract}

Kata kunci: penghijauan; penanaman pohon dan hutan pendidikan

\begin{abstract}
Greening activities as a form of business through tree planting. This activity will be able to provide benefits to the surrounding community in supporting socio-economically in a sustainable manner. This service activity with the aim of: 1) Increasing public and student awareness of the importance of the integrity of the surrounding environment; 2) Providing new experiences to the community and students regarding the procedures for tree planting and sustainable maintenance; and 3) Increase the knowledge of the community and students about tree management in forest areas as a means of utilization for the surrounding community. The service methods used in this activity are socialization, implementation of labor-intensive activities and program evaluation. This service was carried out on February 8, 2021. This reforestation activity was carried out in Batu Bolong Hamlet, Batu Layar Barat Village, Batu Layar District. This greening activity involves students and lecturers of Geography Education, FKIP Muhammadiyah Mataram University and the community in protecting and preserving trees. The results of the activity have an impact on greening the surrounding environment in supporting the forest area. Education in the future..
\end{abstract}

Keywords: afforestation; tree planting and forest education

\section{PENDAHULUAN}

Peraturan Pemerintah No. 26 Tahun 2020 tentang Rehabilitasi dan Reklamasi Hutan merupakan Peraturan Pemerintah yang menggantikan Peraturan Pemerintah Nomor 76 Tahun 2008 tentang Rehabilitasi dan Reklamasi Hutan. Dalam peraturan tersebut bahwa rehabilitasi dan reklamasi Hutan memiliki visi bahwa sumber daya alam berupa Hutan, tanah, dan air merupakan kekayaan alam yang harus tetap dijaga kelestariannya, oleh sebab itu pengelolaan terhadap sumber daya alam dengan satuan unit Pengelolaan DAS harus dilaksanakan secara bijaksana, sehingga dapat mendukung peningkatan kesejahteraan masyarakat.

Kegiatan rehabilitasi dan reklamasi hutan melalui pendekatan partisipatif dalam rangka mengembangkan potensi dan memberdayakan masyarakat. Rehabilitasi diselenggarakan melalui kegiatan Reboisasi, Penghijauan, dan penerapan teknik konservasi tanah. Rehabilitasi dan Reklamasi Hutan, 
keberhasilannya ditentukan oleh besar kecilnya partisipasi masyarakat.

Dalam rangka pengelolaan hutan untuk memperoleh manfaat yang optimal dari Hutan dan Kawasan Hutan bagi kesejahteraan masyarakat, maka pada prinsipnya semua Hutan dan Kawasan Hutan dapat dikelola dengan tetap memperhatikan sifat, karakteristik dan keutamaannya, serta yang selaras dengan fungsi pokoknya yaitu fungsi konservasi, lindung dan produksi. Oleh karena itu, dalam pengelolaan Hutan perlu dijaga keseimbangan ketiga fungsi tersebut. Untuk kepentingan pembangunan bersifat strategis atau menyangkut kepentingan umum yang harus menggunakan Kawasan Hutan, kegiatannya harus diimbangi dengan upaya reklamasi.

Hutan Rakyat sudah sejak lama memberikan sumbangan ekonomi maupun ekologis baik langsung kepada pemiliknya maupun kepada masyarakat sekitar. Namun demikian pada awalnya perhatian para birokrat, pelaku bisnis, pemerhati lingkungan maupun peniliti sangat terbatas. Perhatian memang lebih banyak diberikan pada sumbangan hutan alam yang pada masa-masa awal kekuasaan orde baru dijadikan sebagai salah satu sumber pendapatan Negara. Baru kemudian ketika pada akhirnya pengelolaan hutan alam yang lebih berorientasi pada pendapatan ekonomi dengan dukungan pengusaha kehutanan terbukti tidak mampu melestarikan hutan bahkan menyisakan kerusakan hutan yang sangat parah. Pihak-pihak tersebut sedikit demi sedikit mulai memperhatikan keberadaan hutan rakyat. Bahkan, walaupun nuansa politis dan propagandanya masih domininan dari pada poltical will yang diberikan, pengelolaan hutan berbasis masyarakat telah diakui sebagai salah satu solusi permasalahan kehutanan di Indonesia.

Inisiatif Hutan Rakyat Sejatinya masyarakat telah lama mengenal pola pemanfaatan lahan yang menyerupai hutan rakyat. Bagi masyarakat Jawa Tengah dan sekitarnya lahan tersebut lebih dikenal dengan sebutan " pekarangan " dimana pada lahan tersebut masyarakat menanam berbagai jenis tanaman keras seperti jati, kelapa, randu, dan lain sebagainya. Walaupun sebagian besar hutan rakyat di Jawa berada pada tanah dengan status tanah milik rakyat, pengembangan hutan rakyat sangat erat kaitannya dengan program pemerintah khususnya program penghijauan (Suprapto, 2010).

Dalam rangkaian pengabdian kepada masyarakat Penghijauan Di Areal Hutan Pendidikan Universitas Muhammadiyah Mataram, maka pada kegiatan ini para dosen
Pendidikan Geografi yang dibantu semua organisasi mahasiswa ikut serta dalam program penanaman pohon untuk penyelamatan lingkungan. Kegiatan ini selain untuk mengenalkan dan memberikan pelatihan pada mahasiswa dalam berkontribusi secara langsung dalam menjaga lingkungan, juga ingin memberikan kontribusi pada masyarakat umum melalui kegiatan penanaman pohon. Penanaman pohon melalui Kerjasama dengan semua pihak terutama pihak kehutanan berkaitan dengan bembibitan (Gambar 1). Jenis bibit yang ditanam adalah bibit Pohon Gaharu.

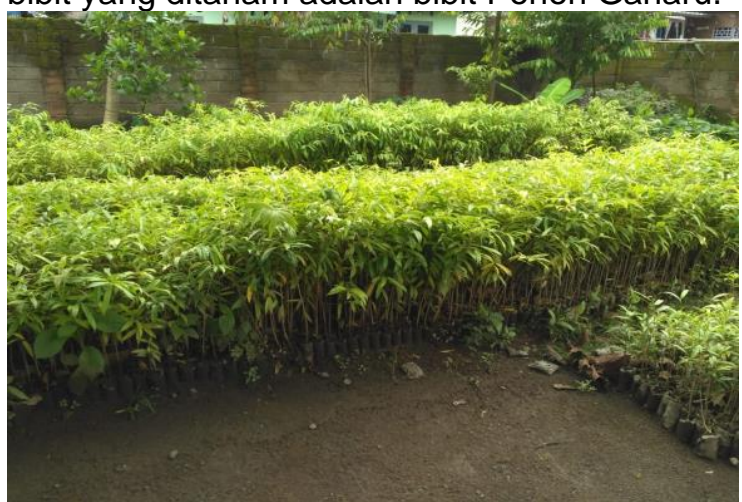

Gambar 1. Pembibitan sebelum kegiatan penghijauan

Adapun manfaat yang dapat diambil dari kegiatan penghijauan melalui penanaman pohon pada hutan Pendidikan Universitas Muhammadiyah Mataram adalah

1. Meningkatkan kesadaran masyarakat dan mahasiswa terhadap pentingnya keutuhan lingkungan sekitar

2. Memberikan pengalaman baru pada masyarakat dan mahasiswa mengenai tata cara penanaman pohon dan pemeliharaan secara berkelanjutan

3. Menambah pengetahuan masyarakat dan mahasiswa mengenai pengelolaan pohon pada daerah hutan sebagai sarana pemanfaatan bagi masyarakat sekitarnya

Kegiatan penghijauan pada hutan Pendidikan universitas Muhammadiyah Mataram tersebut diharapkan pengetahuan diluar bidang keilmuan yang diperoleh para peserta kegiatan penanaman ini dapat membantu usaha pengembangan diri untuk dapat bekerjasama dengan berbagai lapisan masyarakat. Selain itu untuk mengasah rasa peduli terhadap keberlangsungan lingkungan yang seimbang disekitar hutan Pendidikan.

\section{METODE}

Metode yang digunakan pada kegiatan ini adalah penanaman pohon gaharu. Kegaiatan penenaman pohon gaharu ini melibatkan mahasiswa geografi sebanyak 20 orang, dosen geografi sebanyak 10 orang dan 
masyarakat sekitar hutan pendidikan sebanyak 10 orang. Kegiatan pengabdian ini dilaksanakan pada tanggal 8 Februari 2021. Kegiatan penghijauan ini dilaksanakan pada Dusun Batu Bolong Desa Batu Layar Barat Kecamatan Batu Layar. Metode pengabdian yang digunakan dalam kegiatan ini adalah sosialisasi, Pelaksanaan kegiatan padat karya dan evaluasi program.

\section{HASIL DAN PEMBAHASAN \\ Kegiatan Sosialisasi}

Kegiatan penghijauan melalui penanaman pohon pada areal hutan Pendidikan Universitas Muhammadiyah Mataram, kegiatan ini dimulai dari perjalanan dari kampus Universitas Muhammadiyah Mataram kurang lebih $10 \mathrm{KM}$ menuju lokasi hutan Pendidikan. Kegiatan sosialisasi (Gambar 2) ini dilakukan bersama dengan mahasiswa dan dosen geografi Universitas Muhammadiyah Mataram pada tanggal 8 Februari 2021. Pada kegiatan ini dimulai dengan do'a bersama dengan dilanjutkan dengan penanaman secara simbolis oleh ketua Program Studi Pendidikan Geografi Universitas Muhammadiyah Mataram.

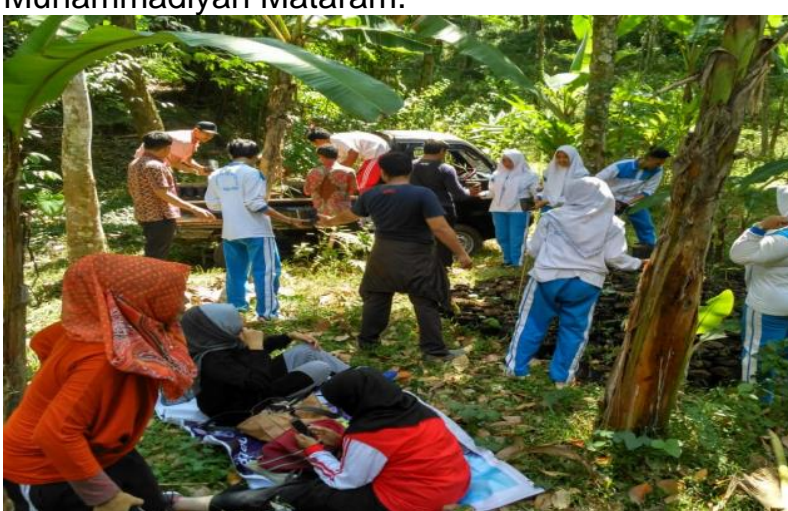

Gambar 2. Sosialisasi sebelum kegiatan penghijauan

\section{Pelaksanaan Kegiatan}

Pelaksanaan kegiatan ini penanaman (Gambar 3) dimulai dengan memilah setiap bibit yang akan ditanami. Salah satu aspek penting yang perlu mendapatkan perhatian dalam rencana penanaman pohon adalah ketersediaan jenis tanaman yang akan ditanam. Penanaman yang dilakukan ini adalah di dalam kawasan hutan Pendidikan Universitas Muhammadiyah Mataram, sehingga dapat dikatakan sebagai kegiatan reboisasi. Oleh karena itu, pemilihan jenis pohon harus berdasarkan pada kriteria yang ada.

Karakteristik daerah hutan Budidaya tanaman gaharu pada lahan hutan merupakan upaya optimalisasi pemanfaatan lahan. Tanaman gaharu adalah jenis tanaman yang menghasilkan produk gaharu, dan jenis ini dikenal dengan nama tanaman karas yang telah dibudidayakan dilahan hutan.
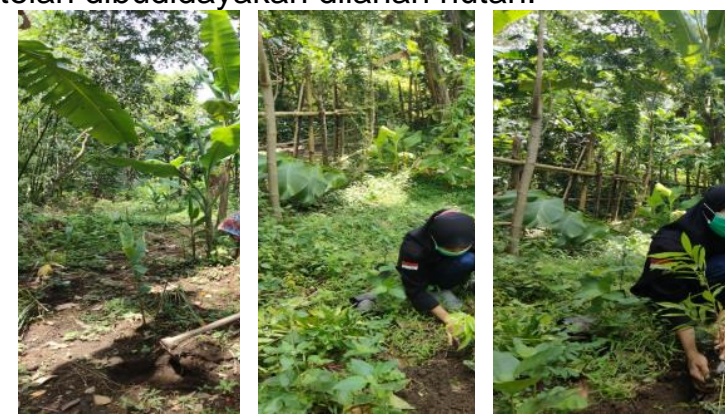

Gambar 3. Pelaksanaan kegiatan penanaman Pohon

Memperhatikan keberhasilan dan manfaat dari gaharu memberikan peluang bagi masyarakat sekitar. Keberhasilan program Kesatuan Pengelolaan Hutan (KPH) dipengaruhi oleh keberadaan masyarakat yang tinggal di sekitar kawasan yang dikelolanya. Kajian ini bertujuan untuk mendeskripsikan pengetahuan masyarakat tentang KPH Lindung Rinjani Barat dan pengelolaannya. Kajian dilakukan pada bulan Agustus hingga November 2015. Data dikumpulkan melalui wawancara terhadap 130 orang dan diskusi kelompok dengan 80 orang dari Desa Pusuk Lestari, Kecamatan Batu Layar; Desa Kekait Kecamatan Gunung Sari, dan Desa Buwun Sejati Kecamatan Narmada yang terletak di Kabupaten Lombok Barat serta Desa Tegal Maja Kecamatan Tanjung yang terletak di Kabupaten Lombok Utara, Provinsi Nusa Tenggara Barat. Hasil kajian menunjukkan bahwa masyarakat di sekitar HL Rinjani Barat menggarap kawasan hutan lindung sebelum terbentuknya KPH Lindung Rinjani Barat. Mereka mengetahui bahwa lahan yang mereka garap merupakan lahan negara dan kawasan lindung yang perlu dijaga kelestariannya. Mayoritas responden mengetahui fungsi hutan lindung dan pengelola HL Rinjani Barat. Pengetahuan tersebut diperoleh dari sosialisasi yang dilakukan oleh KPH pada tahun 2012 . Manfaat HL Rinjani Barat yang dirasakan masyarakat yaitu air, udara sejuk, pariwisata, pekerjaan, HHBK, serta penghasilan. Sebanyak 53\% responden menyatakan telah dilibatkan dalam kegiatan-kegiatan yang dilakukan oleh $\mathrm{KPH}$, di antaranya pembuatan bibit, penghijauan, pengamanan kawasan hutan, pertemuan kelompok penggarap, serta pengelolaan bantuan hewan ternak (Widyaningsih \& Kuswantoro, 2016)

Salah satu hasil hutan bukan kayu (HHBK) yang memiliki nilai komersial tinggi adalah gaharu. Produksi gaharu dapat diperoleh dengan cara memungut dari pohon yang telah mati secara alami. Akibat semakin 
sulitnya mendapatkan pohon yang mati tersebut serta permintaan pasar dengan harga jual yang semakin tinggi, kini masyarakat mencari gaharu dengan cara menebang pohon dan mencacah batang untuk mencari bagian kayu yang telah bergaharu. Tingginya pemungutan gaharu dengan cara menebang pohon hidup di berbagai wilayah, mengakibatkan populasi pohon penghasil gaharu terancam punah. Salah satu upaya konservasi untuk menjaga kelestarian produksi gaharu pada masa mendatang adalah melalui pembudidayaan di berbagai wilayah sentra produksi serta pada lahan-lahan yang memenuhi kesesuaian tempat tumbuh. Tersedianya bahan tanaman berkualitas merupakan faktor dasar yang menentukan keberhasilan budidaya (Sumarna, 2008) dan (Mega, Suanda, Kasniari, Suena, \& Parwata, 2012).

\section{Evaluasi Hasil}

Berdasarkan pelaksanaan kegiatan penghiajaun di areal Hutan Pendidikan Universitas Muhammadiyah Mataram ini memperoleh informasi secara garis besar diantaranya:

1. Melibatkan mahasiswa dan Dosen

Berdasarkan hasil pelaksanaan program penghijauan melalui penanaman pohon pada lokasi hutan Pendidikan Universitas Muhammadiyah Mataram melibatkan mahasiswa geografi sebanyak 20 orang, dosen geografi sebanyak 10 orang dan masyarakat sekitar hutan pendidikan sebanyak 10 orang.

2. Melibatkan Masyarakat sekitar

Keterlibatan masyarakat pada penghijauan melalui penanaman pohon pada sekitar areal hutan Pendidikan Universitas Muhammadiyah Mataram melalui pemeliharaan mulai dari tanggungjawab pemeliharaan sampai tumbuh. Keterlibatan masyarakat dalam penghijauan sangat diperlukan. masyarakat telah terlibat dalamproses perencanaan, penyediaan, pemeliharaan, serta pengawasan kegiatan penghijauan. Masyarakatmenilai kondisi ruang hijau di kelurahan saat ini sudah sangat minim. Kegiatan penghijauan dilakukanoleh masyarakat dengan berbagai motif, antara lain : untuk menambah nilai ekologi, manambah nilaiestetika, mendapatkan manfaat ekonomi, serta alasan untuk mendukung program pemerintah.Keberadaaan stakeholder yang terdiri dari Pemerintah Kota, Pemerintah Kelurahan, Lembaga Non Pemerintah, Swasta / CSR, dan Komunitas / Akademisi telah berkontribusi besar membantu perkembangan kegiatan penghijauan di wilayah studi (Rubiantoro \& Haryanto, 2013), (Rahajeng Kusumaningtyas \& Chofyan, 2012), (R. Kusumaningtyas \& Chofyan, 2013) dan (Tanjung, Sadono, \& Wibowo, 2017).

\section{SIMPULAN DAN SARAN Simpulan}

Kegiatan penghijauan ini dengan penanaman pohon gaharu dapat disimpulkan bahwa kegiatan pengabdian kepada masyarakat ini dilaksanakan dalam bentuk penanaman pohon pada lokasi hutan Pendidikan Universitas Muhammadiyah Mataram dan kegiatan penghijauan ini dilaksanakan secara bersama-sama antara dosen Pendidikan Geografi FKIP Universitas Muhammadiyah Mataram dengan melibatkan organisasi mahasiswa Ikatan Mahasiswa Geografi Indonesia (IMAHAGI) wilayah Nusa Tenggara Barat pada tanggal 8 Februari 2021 yang dilanjutkan dengan kegiatan pemeliharaan oleh masyarakat sekitar hutan Pendidikan tersebut.

\section{Saran}

Dalam mndukung upaya penghijauan pada Hutan Pendidikan Universitas Muhammadiyah Mataram diperlukan:

1. Kerjasama dengan masyarakat sekitar sebagai bentuk kemitraan dalam menjaga lingkungan sekitar

2. Adanya keterlibatan dalam mahasiswa dalam pemeliharaan sampai tumbuh dengan membentuk kelompok mahasiswa sadar lingkungan, sehingga akan mampu mendukung ekosistem berkelanjutan

3. Kedepan semoga bisa masuk dalam kurikulum Bersama semua prodi dalam Kegiatan pemeliharaan lingkungan secara berkelanjutan akan dapat menciptakan suasana yang nyaman, asri, bersih dan indah yang dapat menunjang proses pembelajaran di lingkungan hutan Pendidikan sebagai labotarium

\section{UCAPAN TERIMAKASIH}

Terima kasih pada semua pihak dalam pelaksanaan kegiatan pebghijauan terutama pada pihak Program Studi Pendidikan Geografi FKIP Universitas Muhammadiyah Mataram dan Masyarakat sekitar dalam mendukung terlaksanakan kegiatan ini.

\section{DAFTAR RUJUKAN}

Kusumaningtyas, R., \& Chofyan, I. (2013). Pengelolaan Hutan Dalam Mengatasi Alih Fungsi Lahan Hutan Di Wilayah Kabupaten Subang. Jurnal Perencanaan Wilayah Dan Kota. Https://Doi.Org/10.29313/Jpwk.V13i2.138 
Kusumaningtyas, Rahajeng, \& Chofyan, I. (2012). Pengelolaan Hutan Dalam Mengatasi Alih. Perencanaan Wilayah Dan Kota.

Mega, I., Suanda, D., Kasniari, D., Suena, W., \& Parwata, M. (2012). Formulasi Inokulan Jamur Pembentuk Gubal Gaharu Pada Tanaman Ketimunan (Gyrinops Versteegii). Agrotrop: Journal On Agriculture Science.

Rubiantoro, E. A., \& Haryanto, R. (2013). Bentuk Keterlibatan Masyarakat Dalam Upaya Penghijauan Pada Kawasan Hunian Padat Di Kelurahan Serengan Kota Surakarta. Jurnal Pembangunan Wilayah \& Kota. Https://Doi.Org/10.14710/Pwk.V9i4.6679

Sumarna, Y. (2008). Pengaruh Jenis Media Dan Pupuk Nitrogen, Posfor, Dan Kalium (Npk) Terhadap Pertumbuhan Bibit Pohon Penghasil Gaharu Jenis Karas. Jurnal Penelitian Hutan Dan Konservasi Alam. Https://Doi.Org/10.20886/Jphka.2008.5.2. 193-199

Suprapto, E. (2010). Hutan Rakyat. Seminar Nasional Kontribusi Pengurangan Emisi Karbon Dari Kawasan Hutan Yang Dikelola Asyarakat Secara Lestari Dan Berkelanjutan.

Tanjung, N. S., Sadono, D., \& Wibowo, C. T. (2017). Tingkat Partisipasi Masyarakat Dalam Pengelolaan Hutan Nagari Di Sumatera Barat. Jurnal Penyuluhan. Https://Doi.Org/10.25015/Penyuluhan.V1 3i1.12990

Widyaningsih, T. S., \& Kuswantoro, D. P. (2016). Pengetahuan Masyarakat Tentang Kphl Rinjani Barat Dan Pengelolaannya. Prosiding Seminar Nasional Dan Pertemuan IImiah Tahunan Ke-2 Komhindo „Pengelolaan Hutan Berbasis $K p h^{\prime \prime}$. 